\title{
From In-itself to For-itself:Modern Reconstruction of Rural Culture in the Field of Rural Revitalization
}

\author{
Yin $\operatorname{Jian}^{1, a,{ }^{*}}$ \\ ${ }^{1}$ School of Basic Science, Sheng li College China University of Petroleum,Dongying,Shan \\ dong,China \\ ag99a666@163.com \\ *Yin Jian
}

Keywords: Rural Revitalization Strategy, Rural Culture, Modernity

\begin{abstract}
In a new era of rapid economic and social development, the traditional rural culture is facing the problem of reshaping. It is necessary and urgent to renovate the modernity of rural culture. The process of reshaping should be based on a deep historical foundation with openness, innovation and distinctive features, preferably can resist cultural crisis.In the course of the modern reconstruction, emphasis should be laid on three aspects: Maintain the foundation and focus on integration of rural culture, strengthen the cultural innovation and improve its cohesion, pay attention to raise villagers' ability and foster their confidence.
\end{abstract}

\section{从自在到自觉：乡村振兴视阈下乡村文化的现代性重塑$$
\text { 尹健 } 1, \mathrm{a},{ }^{*}
$$ \\ 1中国石油大学胜利学院, 东营, 山东, 中国 a999a666@163.com \\ *尹健}

关键词：乡村振兴; 乡村文化; 现代性

中文摘要：在经济社会快速发展的新时代, 传统意义上的乡村文化在时代的裹挟之下也面临 着价值重塑的问题。乡村文化现代性重塑有其必要性和紧迫性。重塑应有深厚的历史根基、 兼具开放性和创新能力、有鲜明个性、能抵抗文化危机。重塑需做到养护根基, 注重乡村文 化的整合; 创新文化，增强乡村文化的凝聚力；注重培育，坚定乡民的文化自信。

\section{1. 引言}

乡村是构成传统中国社会的根基。四十年的改革开放实践使我国乡村社会发生了巨大变 迁, 乡村文化在社会的现代化转型中也发生了从传统到现代的调整。在经济快速发展、文化 多元的新时代, 乡村振兴战略必将带来乡村城镇化进程的新一轮发展, 带来乡村的经济进步 和社会结构的变化, 传统意义上的乡村文化在时代的裹挟之下也面临着价值重塑的问题。

十九大报告提出实施乡村振兴战略，国家对农村问题的思考由原来的“城乡统筹” 发展 为 “城乡融合” ，统筹意味着二元结构的存在，“融合” 是指从加快推进农业农村现代化的 基础上消弭城乡之间的对立, 毕竟城乡发展格局失衡将直接影响国家整体发展, 是制约当下 人们追求美好生活的现实障碍。突破制约瓶颈需要诉诸于文化的力量, 美国、日本等先发国 家大多都有一个快速城镇化的过程, 在城镇化率为 $50 \%-70 \%$ 之间时, 城镇化率提升最快, 我 
国 2017 年的城镇化率为 $58.5 \%$, [1]正处于这一快速提升区间。尤其在社会转型、全面建设小康 社会的决胜时期, 发挥乡村文化的作用, 可以为乡村的经济发展提供思想保证和动力支持, 为乡村的社会发展提供凝聚力量和智力支撑。

\section{2. 从传统到现代：乡村文化现代性重塑的基础}

三农问题是我国现代化进程中最大的问题，需要长期的实践。乡村振兴战略的实施给乡 村的新一轮发展带来众多机遇, 但是在乡村建设中也存在着追求物质利益忽视文化生态的做 法。乡村建设切忌重经济建设轻人文精神、重攀高比新轻传统特色, 这实际是对传统文化的 轻视、对乡村精神理解的错位和对乡村发展定位的迷茫。作为乡村文化的主体, 乡民的精神 状态、思想观念、行为方式在快速发展的社会进程中也会随之发生改变。乡村文化构成了整 个乡村内在的精神要素, 反映着乡民的价值取向、精神诉求、思维方式和内在认同, 也在很 大程度上影响着乡村的发展方向和路径。随着时代的转场, 城镇化进程中的农民面临着身份 的消失，大量涌进城市的 “新市民” 和留守乡村的 “新村民” 构成了乡村文化的主体，并且 将乡村文化的因子带入城市, 可以说城镇化进程中的乡村文化无处不在、无时不有, 由自在 到自觉, 重塑的乡村文化的具备坚实的基础。

\section{1 有深厚的历史根基}

文化是人类生存和发展的方式，面对席卷而来的强势文化，乡村文化重塑首先要做的就 是深化自己的人文历史。传统文化蕴藏的文化基因博大精深，是乡村文化重塑的源头活水。 传统社会的乡民在长期的生产和生活实践中形成了优秀的文化传统和文化精神, 对中国乡土 社会有着巨大的影响。从古代到现代, 一代代贤人志士留下的文化观念奠定了乡村文化精神 的坚实基础：孟子描绘的 “出入相友，守望相助，疾病相扶持” 的淳朴乡风，荀子 “先义而 后利者荣，先利而后义者辱” 的义利观，陈寿 “良将不怯死以苟免，烈士不悔节以求生” 的 生死观, 于谦 “粉骨碎身全不怕, 要留清白在人间” 的气节, 老子 “见素抱朴, 少私寡欲” 的修行指引, 孔子 “士不可不弘毅, 任重而道远” 的奋斗精神, 林则徐的 “苟利国家生死以, 岂因祸福避趋之” 的家国情怀……这些传统文化和红色文化中的优异思想因子, 为乡村文化 丰富多彩的发展和自我调节能力的发挥, 奠定了坚实的精神基础。

\section{2 兼具开放性和创新能力}

乡村文化趋向于保守，以小家庭为中心，辐射到家族体系，构成了中国社会的核心。所 谓 “家大立族, 聚族成国” [2]，血缘宗法关系在传统乡村中具有深厚的传承基础。从自发形 成的风俗习惯到有意识的自觉观念, 宗族崇拜的观念对乡民的影响是无所不在的。我国社会 发展的实践已经证明, 随着社会城镇化进程的加快, 以大家族为单位的乡村社会向以小家庭 为单元的城镇融合, 家族、宗族高于一切的群体本位文化被逐渐弱化, 这种生产和生活方式 的转变使乡村文化的自觉性重塑得以由保守走向开放。日渐开放创新的文化观念在拓宽了乡 民知识结构的同时，也拓展了他们的认知空间，农耕文明留下的平均主义思想、依赖意识、 官本位价值观等意识正在渐渐衰减。拥有文化自觉意识的乡民成为传承文化的主体，这种民 间的力量是文化传承中最重要的东西。

\section{3 有鲜明的个性}

乡村文化如果没有鲜明个性, 将无以为计。尊重个人权力和个性发展不仅是是现代化的 重要指标, 更是城镇化进程中我们必须遵循的价值尺度。地域不同, 乡村文化的表现形式迥 异。如果想要改变民众的思想观念和行为模式时, 必须从乡村文化个性着手。乡村文化的传 承, 在于尊重不同地域乡土民情的需求, 以渐进方式促进人与人之间关系的和谐, 在不知不 觉间, 让人深受感染, 把观念传递给他人。乡民从小就开始获得某种价值理念, 进而使群体 表现出集体的特征, 形成中国人的国民性。乡村文化现代性重塑的主旨就在于人的个性应得 
到解放, 得到充分的尊重和发展。社会越开放, 就越能够容纳不同的个性追求, 既可以有积 极入世，“穷则独善其身，达则兼济天下”的仁人，也可以有超然尘外、自甘落寞的隐士。 不同文化间的相斥相吸, 使乡村文化丰富了自己的内容, 经过乡土社会的选择, 最终得以完 善自己的文化形象，从社会伦理、文化表述、文化表象等方方面面凝聚为民族精神的主体内 容。

\section{4 能抵抗危机}

千百年来, 农村始终是存在文化危机的地方。文化多元裹挟了文化危机，积极建立有用、 务实、高效的思维引导体系愈发重要。“文化的问题弥散于经济和社会问题之中” [3]漫长的 生产实践给乡村文化打上了以自然经济为基础的农业社会文化的烙印, 道德与政治水乳交融, 是乡村文化的重要特征, 反映了乡村文化的伦理本位。现实中户籍制度的福利是否均衡、农 民间收入差距是加大还是缩小、义务教育的优质资源分配是否充分、医疗保障是否到位等问 题处理不当都会蕴藏各种危机。文化危机首先具有非复原性, 亦即一旦文化或信仰被否定了, 就会产生新文化, 危机一来, 原来的制度不能被复原; 其次文化危机具有普遍性; 再次, 社 会中的旧结构主体与组成部分的分离, 会发生诸如指挥不灵的现象; 最后, 危机的发生是对 文明基本原则的背离。要驯服危机, 就需要乡村文化积极主动地引领和担当, 将自发性的文 化引向自觉性文化, 主旨是重秩序而非紊乱, 生产和生活方式要丰裕而非饥饿, 价值观念重 传统美德而非腐败, 知识系统重理性而非愚昧。

\section{3. 从自在到自觉: 乡村文化现代性重塑的路径}

自在性文化是人们对于社会生活的感性认识, 指悠久历史中遗留的衣、食、住、行以及 风俗习惯等社会心理的总和。以血缘关系连接的乡村文化的思想内核是一种 “群体意识” , 农民的生产方式和生活方式并由此造成的农民的观念、价值都对中国文化产生了巨大影响。 我们只能诉诸于理性思考, 将传统观念、道德观念、伦理价值等借助于自觉性文化表现出来。

自觉性文化是人们对于社会生活的理性认识，指通过共同的生活经验与体认，所形成的 具有凝聚作用的文化认同。在乡村历史发展的进程中, 自觉性的乡村文化是有效解决乡民生 存中遇到的各种矛盾的精神武器, 是乡民面临种种选择时所秉持的一致的价值观念、思维方 式和行为方式。乡村文化的现代性重塑, 既要避免自高自大, 又要避免自卑自贱, 这个重塑 的过程所需的时间会比较长, 也需要更大的自觉, 但或许是唯一可行的道路。

\section{1 养护根基, 注重乡村文化的整合}

文化重塑首先考虑的应该是如何有利于乡村的发展。优秀的传统文化是乡村文化的深厚 根基, 作为价值体认的乡村文化一直与优秀传统相连接, 有深厚的文化底蕴; 优秀传统文化 应该也必须成为重塑后乡村文化的基因和命脉。需要注意的是, 现代性的重塑并不是去复古 传统, 相反重塑的光辉应能照亮以前的岁月, 所以乡村文化的现代性重塑应该做到既不脱离 传统, 又不仅限于乡村, 在保持自身文化独立性和自主性的同时, 积极进行文化整合, 在多 元文化中展现中华文化的独特鬼米力，在文化整合中进行良好的自我调节和自我修补。

\section{2 创新文化, 增强乡村文化的凝聚力}

乡村文化只有创新和发展才有影响力和生命力, 不断丰富的文化内涵构成了鬼力无穷、 活力无限的未来乡村, 千百年来人们对故乡的滕恋、对家国的依赖, 化为剪不断的乡愁, 也 是乡村文化凝聚力的深层原因, 深藏在每位乡民的内心深处, 其人文关怀的无限韵味和诗意 表达让人的心灵有栖息安顿之处。乡村优秀文化的传承要以深入挖掘中华优秀传统文化的价 值理念为基础, 同时做到与时俱进、积极推进文化创新。增强文化凝聚力首先乡村文化服务 应以乡民喜闻乐见的方式提升起道德和文化素养, 改善乡村文化环境; 其次乡村文化产业发 展应该能够反映乡村的文化特色和乡民的文化追求; 再次应创造适宜的人居环境, 不盲目追 
求经济效益, 适宜居住是和谐乡村的重要特征, 且能保持自身独特的村容符号, 避免同质化 模式; 最后, 应创建新的科学知识体系, 把它应用于乡村政治、经济、教育等各个方面, 从 而在理性基础上建立起现代乡村的经济体制、文化体系并具备更为开阔的文化视野。

\section{3 注重培育, 坚定乡民的文化自信}

说到底城镇化更多地还应该是人的城市化, 乡民文化意识的培养是乡村文化重塑的中最 能动、最活跃的因素, 也是培育乡村文化内生增长能力的着力点。针对乡村儿童、青少年加 强文化教育, 针对乡民加强精神引领, 进行文化认同教育。在乡村生活的人们应该正确理解 自己传承创造的乡村文化, 毕竟乡村文化是乡村文明在城市的缩影, 是社会和谐在乡村的集 中体现, 以人为本、全面发展, 既是治国理念, 也是乡村文化的精髓。马克思曾经提到人在 “劳动过程结束时得到的结果, 在这个过程开始时就已经在劳动者的表象中存在着, 即已经 观念地存在着” [4]。乡村文化的主体是乡民，只有长期处于劳动实践过程中的乡民有了文化 自觉的意识, 才能形成文化认同, 进而达到乡民的文化自信, 亦即最终实现农民的文化自觉 才能够将文化的力量施加到经济社会的发展中。人通过劳作获得温饱, 通过知识获得解放, 通过创造获得自由，故而乡村文化的主体更要承担起历史使命、政治使命和文化使命。

\section{4. 结束语}

文化自信的基础是乡民的文化认同，文化认同的内容主要包括从社会观角度认同竞争和 能力, 而不是差异、等级和尊贵; 从政治秩序方面认同革命和改革而不是墨守成规; 从信仰 角度认同科学而不是迷信。毕竟乡民的文化自觉意识成熟了，才会有 “核心理念上的深层次 文化认同” [5]。所谓 “行” 先于 “知” ，我们要在长期农耕实践所形成的自发性文化中寻求 文化自信的因子, 然后以 “知” 促 “行”, 亦即有了文化自觉的意识, 才能最终化为文化自 信的坚定行动。

\section{致谢}

本文为山东省教育科学 “十三五” 规划自筹课题《地域优秀传统文化融入高校思政教育 的途径研究》 (BCH2017005) 、山东省高校人文社会科学研究计划《黄蓝战略下东营城市文 化竞争力提升途径研究》（J15WE43）的阶段性成果之一。

\section{References}

[1] Liang Run, China's urbanization, human capital and long-term economic growth,[EB/OL] http://economy.caijing.com.cn/20180212/4407456.shtml.

[2] Zheng Da.Hua,Peng Ping.Yi, Social Structure Change and Modern Cultural Transformation, pp. 17, 2008.

[3] Fredric. Jameson, On Globalization and Culture//Wang Fengzhen,Lectures by Western Famous Teachers, pp. 5, 2005.

[4] K.Marx, F.Engels, Collected Works of Karl Marx and Frederick Engels, People's Publishing House, vol. 2,. pp.170,2012.

[5] Zhao Xia,The Order Transformation and Value Reconstruction of Rural Culture, Hebei People's Publishing House, pp.5, 2013 